\title{
STUDY ON THE HOLOTHUROID FAUNA (ECHINODERMATA : HOLOTHUROIDEA) INHABITING THE SHALLOW WATERS. OF THE EGYPTIAN RED SEA
}

\author{
Ahmed M. Hellal ${ }^{1}$; Mohamed M. Abou Zeid ${ }^{1}$; Abd-Allah El- \\ Sayed ${ }^{2}$; Mohamed El-Samra ${ }^{3}$ and Mohamed H. Hassan ${ }^{3}$ \\ 1) Zoology Department, Faculty of Science, Al-Azhar University \\ 2) Marine Science Department, Faculty of Science, Suez Canal Univ. \\ 3) National Institute of Oceanography and Fisheries, Suez
}

key word: Ecinodermata - Holothuroidea - Red Sea - Gulf of Aqaba Gulf of Suez.

\begin{abstract}
$A^{n}$ intensive survey was carried out on the shallow water of the A Egyptian coast and Islands of the Red Sea down to $22^{\circ} \mathrm{N}$ Lat. including Gulfs of Aqaba and Suez to study the holothuroid fauna. A total number of 32 holothuroid species was collected, belonging to 8 genera, 3 families and 2 orders. A taxonomic key to the species level was constructed to facilitate the identification of the collected species. Among the obtained species, Bohadschia mitsioensis, Bohadschia vitiensis, Holothuria (Thymiosycia) conusalba, Labidodemas rugosum, Holothuria (Platyperona) crosnieri, Holothuria (Mertensiothuria) albofusca and Stichopus horrens were recorded for the first time from the entire Red Sea. Among the 32 species, 5 species $(15.6 \%)$ were cosmopolitan, 6 species $(18.7 \%)$ were widely distributed , 18 species $(56.3 \%)$ were restricted in their distribution to some places in the Indian Ocean and 3 species $(9.4 \%)$ were endemic to the Red Sea. Study on micro-habitat distribution showed that species of genera Actinopyga and Bohadschia were surf zone species. and most species of genus Holothuria were fugitive species, while species of subgenera Cystipus, Theelothuria and Metriatyla were mainly fossorial species.
\end{abstract}

\section{INTRODUCTION}

Holothurians (known as sea cucumbers) are abundant and more diverse and are likely important members in the ecosystem (Magnus, 1967; Fishelson, 1971; Hughes, 1977; Sloan et al., 1979; Cherbonnier, 1988; and Price, 1982). Most holothuroid species fed 
mainly on organic contents of mud and ooze, while others shovel detritus, so they are responsible for causing significant changes in the composition of the sea floor (Yamaguchi, 1956; Hammond; 1982; Moriarty, 1982).

Attempts to study holothuroids are usually faced with identification difficulties and this probably explains why the holothuroids of the tropics have been accorded far less attention than they deserve. The identification of all genera and species of holothuroids depends almost entirely on the form and combinations of the calcareous spicules found in the body wall and podia. These are commonly subdivided into three-dimensional units (i.e. tables) near the surface, and two-dimensional ones (i.e. buttons and rods) deeper in the body wall. The forms of calcareous ring, the arrangement of the tube feet and tentacles, the presence or absence of the anal teeth or papillae, polian vesicles, stone canal and cuverian organs also provide useful taxonomic characters (Pearson, 1914; Cherbonnier, 1952, 1955, 1967, 1979 a \& b, 1980 and 1988; Deichmann, 1958; Rowe, 1969; and Clark and Rowe, 1971).

Rowe (1969), Clark and Rowe (1971) and Cherbonnier (1988) confirmed previous studies of spicules and mentioned that spicule complexity forms a sound basis for recognizing groups of species within Holothuria sensu extenso. Pearson (1914) divided the genus Holothuria into five subgenera namely Bohadschia Jaeger, Actinopyga Bronn and three new subgenera Argiodia, Halodeima and Thymiosycia. Later on, Panning (1929-1935), in his revision of Holothuria, recognized Actinopyga and Bohadschia with Microthele as subgenera and arranged the remaining 113 species within Holothuria sensu stricto.

On the basis of the holothurian collections of the British Museum and the existing literature, an attempt was made by Rowe (1969) to deal with the balance of those species not taken into consideration by Deichmann (1958) and to bring her system into line with the rules of nomenclature. Rowe (1969) concluded that, excluding those of Actinopyga, Bohadschia and Labidodemas, the number of species of genus Holothuria considered to be valid was about 114 species. He grouped these species into 17 more or less clearly distinct supraspecific taxa, among them four subgenera were new.

Cherbonnier (1955) in his work at the Farsan expedition in the Red Sea recorded 44 holothurian species representing 16 genera and belonging to three orders. These were (a) Aspidochirotida which has 
STUDY ON THE HOLOTHUROID FAUNA

(ECHINODERMATA : HOLOTHUROIDEA ) INHABITING THE SHALLOW WATERS OF THE EGYPTIAN RED SEA

has two families, Holothuriidae.(29 species). and Stichopodidae (only Stichopus monotubuculatus); (b) Dendrochirotida comprising two families, Cucumariidae (6 species) and Phyllophoridae (2 species); and (c) Apodida that includes the remaining 6 species, all of them belong to family Synaptidae. In 1962, Cherbonnier added to our knowledge 15 species of holothuroids from the Gulf of Aqaba. Clark and Rowe (1971) recorded 66 species of holothuroids from the Red Sea, distributed on 5 families. They have recorded 46 species of family Holothuriidae, 11 species of Synaptidae, 4 species of Cucumariidae, 3 species of Phyllophoridae and finally two species belonging to family Stichopodidae. In addition, Cherbonnier (1979 a $\&$ b) described a new dendrochirote species, Stereoderma perexigua and new aspidochirotid species, Holothuria (Metriatyla) tortonesei from the Red Sea and added two species, Stichopus pseudohorrens and Holothuria (Stauropora) hawaiiensis to the Red Sea holothurian fauna Also, Cherbonnier (1980) described a new apodid species, Protankyra suroitae from the southern Red Sea.

Price (1982) compared between the echinoderm fauna of the Arabian Gulf, Southeast Arabia and the Red Sea. He recorded 83 holothuroid species from the Red Sea and its two guifs and mentioned that out of 83 holothuroid species 55 species were found in the Red Sea proper, 39 species from the Gulf of Aqaba and 36 species from the Gulf of Suez. But Price's list included 8 unconfirmed species. There have been new holothuroid records in recent years (e.g. Cherbonnier, 1979 a \& b; 1980 and Price, 1982), but in general, the literature on actual number of holothuroid species of the Red Sea is limited, and in some respects, lacking.

Deichmann (1958) studied the ecological distribution of holothuroids on the reef and connected the distribution patterns with the spicules, tentacles and body shape. She recognized three distinct ecological divisions, namely surf zone, fugitive and fossorial species.

The current study was carried out to present an intensive survey on the shallow water holothuroid fauna of the Egyptian Red Sea coasts and islands, and to construct a taxonomic key to the species level, based on the collected species. Also, it aims to facilitate further biological and to reduce ecological studies of the local marine fauna and the environmental disturbance that threaten them. 


\section{MATERIALS AND METHODS}

Seventy nine stations along the Egyptian Red Sea coasts and islands, in addition to the Gulf of Suez and Gulf of Aqaba'were surveyed during the period from September 1995 to December 2000 (Fig. 1). At each site different data were recorded such as locality, community siructure, substrate, and holothuroid distribution. Holothuroids were collected by SCUBA diving from the subtidal arcas, while they were collected by hand and snorkeling in the intertidal areas. Some specimens were preserved in $10 \%$ seawater formalin for taxonomical studies.

At the laboratory, holothuroids were sorted into farrilies, genera and species. For the preparation of spicules, four pieces were taken from each specimen, from the dorsal and abdomen surfaces and from anal and the oral areas; A slide of spicules from each piece was prepared according to the method described by Cherbonnier (1955). The slides were examined under a Nikon bigh power microscope. Also, the calcareous ring was taken out from the oral region of each individual for examination.

Identification of each specimen and species were carried out, using the keys of Clark (1921), Rowe (1969), Clark and Rowe (1971), Price (1983), Guille et al., (1986) and Cherbonnier (1988). In addition, other important taxonomic works such as Cherbonnier (1955, 1962, 1979 a \& b and 1980), James and Pearse (1969), and Price (1981 \& 1982) were also used. Specimens of uncertain identity were positively identified and compared with the echinoderm reference collection at the Marine Biology and Fishes Section, Zoology Department, Faculty of Science, Al-Azhar University.

A general layout of the holothuroid body indicating the different structures is given in Figure (2). Examples of terms used in the description of the species, and constructing the key are illustrated in Plate (1).

\section{RESULTS}

The results revealed that the total number of collected holothuroid species is 32 belonging to 8 genera, 3 families and 2 orders. Family Holothuriidae includes the largest number of species, being 27 species followed by family Synaptidae which comprises 3 species, while the remaining 2 species belong to family Stichopodidae. 
Key to the species of holothuroids collected from the Red Sea

Body sausage shaped or spindle shaped, body wall more or less thick and muscular, covered with podia and papillae, or only

1- with papillae; $10-30$ peltate tentacles. Spicules: tables; perforated plates; rod unique or branched; buttons; cups; ellipsoid, hollow, fenestrated, rosettes or miliary granules .

\section{ORDER: ASPIDOCHIROTIDA}

Body vermiform or snake-shaped, body wall usually thin and fragile with no podia, no papillae; $10-25$ pinnate tentacles; no

1. retractor muscles of the pharynx, no tentacle ampulla or respiratory trees. Speciules: anchors associated with anchor plate; irregular tables, rods present .

ORDER: APODIDA. (Family: Synaptidae).

Ten to fifteen tentacles with up to 40 digitations webbed; stock of anchor irregularly branched with a various number of knobs very spinose; stone canal very numerous; usually no cartilaginous ring .

\section{Opheodesoma kamaranensis (Clark, 1951)}

Fifteen to twenty seven tentacles with more than 40 digitations

2- not webbed; stock of anchor unbranched; one stone canal; cartilaginous ring commonly presents.

3. enty-five tentacles with 40 to 45 digitations; no rosettes; 50 and more polian vesicles .

\section{Polyplectana kefersteini (Selenka, 1867)}

teen to sixteen tentacles, sometimes less, with 30 to 40

j. digitations; characteristically large anchors, anchor plates subrectangular, pseudorosettes present; about 10 polian vesicles .

Synapta maculata (Chamisso and Eysenhardt, 1821)

dy with sole or trivium usually flattened; "bivium" dorsal, convex and covered with numerous papillae; gonads in a single tuft to

4- the left of the dorsal mesentery. Spicules: tables; buttons simple or knobbed, sometimes modified or ellipsoids hollow fenestrated; $\mathrm{C}$ and $\mathrm{S}$-shaped rods never present .

Body with square or trapezoidal section; bivium covered with

4. papillae (larger than Holothuriidae); no cuverian organ; gonads in two tufts one each side. Spicules: branched rods or numerous $C$ and S-shaped rods .

Family: STICHOPODIDAE. (Genus: Stichopus).

5. Body brood, approximately rectangular in cross section, 
flattened ventrally; anus has 20 tentacles; colour usually mottled brownish-yellow or khaki with dark papillae, giving dotted appearance (in live specimens). Spicules: tables of the dorsal papillae ended with double crown of spines; cruciform rosettes and curved rods; large C-shaped rods, which may have branches.

Stichopus variegates Semper, 1868.

Body trapezoidal in cross section; anus has 18-20 tentacles; colour whitish to greenish with brownish spots. Spicules: enlarged tack-like tables in dorsal papillae with conical pointed spire, perforated plates present, $C$ - shaped rods not branched .

Stichopus horrens Selenka, 1867.

Body wall very thick and muscular; podia and papillae short, close together, regularly arranged on the "bivium" and

6- "trivium". Spicules: numerous branched rods, usually dichotomously lobed; tables, buttons, rosettes; perforated plates 7 never present .

Body wall thin to thick; podia irregularly arranged on a ventral often flattened "trivium" and scattered papillae on often convex "bivium". Spicules: tables of some forms nearly always present; buttons, rods, rosettes, perforated plates present or absent; dichotomously lobed rods, if present, then only in combination with tables, never on their own .

7- Anus guarded by five enlarged calcified papillae or anal "teeth".

Genus: Actinopyga.

7'- Anus not guarded by five enlarged calcified papillae though five groups of smaller papillae may be present.

\section{Genus: Bohadschia.}

Twenty five tentacles; tube feet scattered all over the ventral side; colour very variable, usually chocolate-brown above,

8- yellow-white below; length up to $40 \mathrm{~cm}$; spicules consisting of branched rods and small rosettes above, rugose rods and ovate grains below .

Actinopyga mauritiana (Quoy and Gimard, 1833)

Usually 20 tentacles; tube feet usually restricted to three bands

8'- along the ventral radii (except in A. serratidens); colour various, commonly mainly brown or black, grey; spicules consisting of branched rods and rosettes on both sides.

9- Cuverian tubules present; colour grey dorsally with white brownish splash blots.

Actinopyga crassa Panning, 1944.

9'- Cuverian tubules absent; colour uniformly brown or black, sometimes palterned.

10- Tube feet uniformly scattered on the ventral side; colour usually uniformly dark brown or black, rarely lighter below. 
Actinopyga serratidens Pearson, 1903.

10'. 'Tube feet restricted to the radii ventrally; colour lighter below and the upper side often patterned.

11. Podia arranged in 8-10 rows for each radius and intertadius dorsally; complicated rosettes forming buttonets dorsally.

Actinopyga plebeja (Selenka, 1867).

11. dia irregularly dispersed on the radii and interradii dorsally; picules consisting of richly-branched rods and rosettes dorsally.

Actinopyga echinites (Jaeger, 1833).

Ventral side with uniformly single colour, though there may be

12- dark spots around the podia; numerous podia scattered on both sides.

12. Colour lighter ventrally with many large patched of yellowish colour; few podia widely dispersed on both sides.

Bohadschia mitsioensis Cherbonnier, 1988.

13. Dorsal podia ringed with dark maroon to brown contrasting with light yellowish to brown ground colour.

Bohadschia vitiensis (Semper, 1867)

13. Dorsal colour fairly uniform reddish-brown or darker, ton contrasting spots around the podia.

14. Dorsal and ventral sides with uniformly dark colour; no conical papillae on the dorsal side

Dorsal colour fairly uniform reddish brown, ventral colour

:4'- white to yellowish; some large conical papillae dispersed among podia dorsally.

Bohadschia tenuissima (Semper, 1868)

15- Dorsal colour blackish, ventsal colour dark maroon.

Bohadschia cousteaui (Cherbonnier, 1954)

15'. Colour on both sides uniformly pale brown.

Bohadschia stcinitzi (Cherbonnier, 1963)

Body wall smooth; colour of live and at least recently preserved specimens pinkish-white with brownish purple ends, tentacles and podia bright yellow; calcareous ring slender and

16. ribbon-like; podia restricted to the ambulacral area. Spicules few, consisting of reduced tables having a short spire ending in a cross with up to five branches; buttons when present smooth and irregular, often incomplete or deformed and minute rods.

\section{Lahidodemas rugosum (Ludwig, 1875)}

Body wall not smooth; colour of live and preserved specimens

16.- variable, but not as above; calcareous ring more or less stout, not ribbon-like; podia in the form of locomotory pedicels on the ventral surface which is often flattened, and more or less 
sensory conical papillae on the dorsal surface which is often arched. Spicules numerous and diverse, consisting of tables, buttons, fenestrated spheres, rosettes, rods in various combinations.

\section{Genus: Holothuria}

Colour of live and preserved specimens uniformly blackishbrown or blackish- purple dorsally and pink ventrally.

17. Spicules: tables, with disc reduced or absent, always in combination with rods, perforated plates, rosettes, never with buttons or pseudobuttons.

Holothuria (Subgenus: Halodeima).

Colour of live and preserved specimens variable but not as above (except for Holothuria (Mertensiothuria) leucospilota).

17'- Spicules: tables with developed disc always in combination with buttons and pseudobuttons, sometimes with rosettes or rods.

Colour uniformly black or dark brown; body usually covered with sand, except for several pairs of bare patches dorsally; tables with reduced disc and moderately high spire, ending in a few spines forming a maltese cross when viewed from above.

Holothuria (Halodeima) atra Jaeger, 1833.

Colour blackish-purple dorsally and bright pink ventrally; body not covered with a layer of sand; tables discless with moderately high spire ending in a cross with a hole in the centre when viewed from above .

Holothuria (Halodeima) edulis Lesson, 1830.

Spicules: buttons always knobbed or rugose or modified to form

19. hollow fenestrated ellipsoids; tables always strongly developed, sometimes modified into hollow fenestrated spheres.

Spicules: buttons smooth, regularly or irregularly developed, or

19.- pseudo-buttons often twisted; tables variously developed, never modified into hollow fenestrated spheres

Buttons simple, with moderate size irregularly arranged knobs and 3-6 regular pairs of holes, buttons never modified into hollow fenestrated ellipsoids; table well developed with smooth disc, spire terminating in a cluster of small spines.

Holothuria (Subgenus: Metriatyla) scabra Jaeger, 1833. Presence of buttons modified to form fenestrated ellipsoids and sometimes of buttons; tables with disc usually knobbed, spire terminating in a cluster of small spines or forming fenestrated hollow spheres.

No collar of papillae around the base of the tentacles. Spicules: tables with disc usually knobbed, spire low, bearing many short 
STUDY ON THE HOLOTHUROD FAUNA

spines which are sometimes so numerous and closely crowded obscure the disc forming a fenestrated sphere; distinctly knobbed buttons with 3.8 pairs of relatively small holes, some buttons modified into fenestrated ellipsoids

Holothuria (Subgenus: Cystipus) sucosa Erwe, 1919. Collar of papillae around the base of the tentacle. Spicules: tables stout, well developed, spire moderate or high, never

21'- modified into hollow fenestrated spheres; buttons either with simple irregular knobs of moderate size modified into hollow fenestrated ellipsoids.

Holothuria (Subgenus: Theelothuria) spinifera (Theel, 1886). Spicules: tables with low to high spire terminating in a ring or cluster of small spines, disc usually squarish or octagonal with a - large centrally-placed cruciform hole, one or more smaller holes alternating with each arm of the central cross giving the disc

22- very characteristic appearance, the rim of the disc smooth slightly turned up to give the table a "cup and saucer" in lateral view; buttons variable, oval smooth or rugose, occasionally incomplete or reduced, complete buttons usually with 3-6 pairs of holes.

Holothuria (Subgenus: Stauropora) hawailensis (Fisher, 1907).

22'- Spicules: tables variously developed, never with the central hole of the disc cruciform in shape; buttons variously developed.

Spicules: tables usually well developed, the rim of the disc not

23- spinose (smooth); buttons not twisted, sometimes flat and thin with or without an apparent longitudinal ridge, outline regular or isregular.

Spicules: tables more or less well developed, disc rim usually

23'- spinose or notched: buttons irregular or twisted, never flattened, lacking any appearance of a median longitudinal ridge.

Spicules: table well developed, disc smooth and rounded usually with ten or more peripheral holes, spire of moderate height

24- ending in several small spines; buttons oval, thin flat, median longitudinal ridge present, three to six pairs of relatively small holes, buttons irregular in outline rarely regular

Holothuria (Subgenus: Platyperona)

Spicules: table fairly stout, disc smooth, squarish in outline usually with eight regular peripheral holes spire ending in a

24'- cluster of small spines; buttons not thin or flat and lacking longitudinal ridge, usually with three (rarely 4 or 5) pairs of comparatively large holes and regular in outline.

Holothuria (Subgenus: Thymiosycia).

25- Spicules: tables typical, disc circular with central wavy large 
hole and eight large peripheral ones, a small hole entering in between each tow holes, spire moderate ending in a cluster of small spines; buttons with three to four pairs of irregular holes.

Holothuria (Platyperona) difficilis Semper, 1868.

Spicules: tables dominant and typical, disc circular with central large hole and 8-10 peripheral ones; large tables multi-

$25^{\circ}$ - perforated with high spire consisting of 4 pillars and 6-8 arches ending in a cluster of small and large spines; buttons with five to six pairs of regular holes.

Holothuria (Platyperona) crosnieri Cherbonnier, 1988. Body surface relatively uniform in appearance, podia not

26- prominent or large; colour cream or orange-brown; spicules small, tables with narrow disc rim.

26'. Body with conspicuous or large podia; colour not as above; spicules large, tables with thick disc rim.

Colour cream, often with paired black spots dorsally forming transverse bands. Spicules: tables with square disc and four

27- large central holes and usually four much. smaller ones perforating the narrow disc rim; buttons small with 3-4 pairs of small holes and thick outline.

Holothuria (Thymiosycia) arenicola Semper, 1868.

Colour orange-brown with brown spots forming longitudinal series dorsally, mouth surrounded with white ring. Spicules:

27. tables with quacirangular disc with large four holes and four large ones in disc rim; buttons smooth with three pairs of large holes.

Holothuria (Thymiosycia) conusalba Cherbonnier and Feral, 1985.

Colour mottled grey to reddish brown, often with large rose and dark spots dorsaliy; podia yełlowish and placed on warts, giving body wall a rough and irregular appearance. Spicules: tables with small disc having eight peripheral holes (four holes large alternating with four small ones); buttons regular with three pairs of holes.

Holothuria (Thymiosycia) impatiens (Forskal, 1775).

Colour greenish brown to maroon dorsally and cream ventrally, podia large, pointed and yellow, dorsal tegument covered with 4-6 longitudinal serics of white warts alternating with yellow to

28'- pale reddish ones. Spicules: tables with circular disc and four central holes, disc having twelve peripheral holes which are often of unequal size; buttons regular or irregular with three rarely five pairs of holes.

Holothuria (Thymic: $\therefore$, tilla Lesson, 1830

29- Sixteen to thirty tentacles. Spiculer: tables with rim notched or 
festooned, with low spire terminating in a wide ring of often irregular spines; pseudobuttons abundant, smooth, usually irregular and often reduced to a single row of three or four holes, occasionally buttons quite regular with three pairs of holes; presence of collar papillac around the base of the tentacles and of anal papillae.

Holothuria (Subgenus: Lessonothuria) pardalis (Selenka, 1867).

Eighteen to twenty tentacles. Spicules not strongly developed, rim of disc usually spinose, spire low terminating in ring of 29'. Spines, tables occasionally very reduced or incomplete; buttons irregular, usually with three pairs of holes (rarely five), or else incomplete forming small lobed rosette-like bars; no collar of papillae around the base of the tentacle.

Holothuria (Subgenus: Mertensiothuria).

Colour uniformly bright black on both sides; podia large, conical and thick forming clear warts on the ventral side only.

30. Spicules: tables reduced with spinose disc and four holes centrally, disc rim with 6-8 peripheral holes, spire low terminating in a cluster of spinelets; buttons incomplete, sometimes regular buttons with three pairs of holes present.

Holothuria (Mertensioth uria) papillifera (Heding, 1938).

Colour blackish, brown dorsally, ventral side with palc or

30'. yellowish colour; podia small, not thick and present on both sides. Spicules: tables disc with more than 8 peripheral holes; presence of pseudobuttons of various forms.

Colour uniformly blackish purple dorsally, and pale ventrally; podia on both sides restricted only to radii. Spicules: tables with

31- spinose, disc small with four central holes and variable number of peripheral ones, spire low and terminating in a cluster of 8-12 spines; some regular buttons with 3-5 pairs of holes, many pseudobuttons and variable.

Holothuria (Mertensiothuria) leucospilota (Brandt, 1835) Colour brown chocolate dorsally and white yellow ventrally, anus circled with pale maroon colour; podia on both side distributed on radii and interradii. Spicules: tables having

31'. circular, wavy disc with four large central holes and 10-12 peripheral ones, spire low ending in a cluster of spinelets and without central hole; buttons large with 3-6 pairs of holes, pseudobuttons small.

Holothuria (Mertensiothuria) albof fusca Cherbonnier, 1988. 


\section{DISCUSSION}

In the present study, the total number of holothuroid species recorded in the Egyptian coast of Red Sea is 32 species, belonging to 8 genera, 3 families and 2 orders. Comparing the number of species collected in the current survey with surveys conducted in other areas of the Red Sea, reflects clearly the low diversity of holothuroids in the Egyptian coast. Such findings are in agreement with the classification of Clark and Rowe (1971) where they put the Red Sea in the fourth rank according to the diversity of species among the Indo-Pacific regions. Such pattern agrees with the general opinion that the Red Sea fauna is impoverished compared with the fauna of the Indo-Pacific (Evans et al., 1973; Hughes and Keij, 1973; Kimor, 1973; UNESCO, 1976; Bemert and Ormond, 1981; Price, 1982 and Campbell, 1987).

Despite the fact that the collected number of species was low, the current survey could be considered as pioneer in this field. Most of the holothuroid records from the Red Sea were from areas other than the Egyptian coast. Except for the scattered literature on examined specimens by Cherbonnier (1955, 1962, 1979 a \& b, 1988), James and Pearse (1969), Clark and Rowe (1971) and Price (1982), no taxonomists have so far made an intensive study on the Egyptian Red Sea holothuroids. However, the faunal patterns can be a strong reflection of sampling plan and the collecting method used.

The examination of the collected data also proved a strong rejationship between the obtained fauna and those recorded from other areas in the Indo-Pacific region. For example, Cherbonnier (1988) recorded 122 holothuroid species from Madagascar; our collection contained 17 species $(13.9 \%$ ) of such fauna. Out of 147 holothuroid species recorded by Clark and Rowe (1971) from East Indies, 20 species $(13.6 \%)$ were identical with species recorded in the present study. Clark and Rowe (1971) reported 115 holothuroid. species from north Australia, of which 18 species (15.7\%) were also recorded in the present study. The New-Caledonian holothuroid fauna amounted 54 species by Guille et al. (1986) among them $31.5 \%$ (17 species) were recorded from the Red Sea in the present study.

Price (1982) recorded 83 holothuroid species from the Red Sea but he did not give the specific locality (i.e. north or south). However, in his discussion he mentioned that 4 species were of the 
deep sea fauna (under 100 meters depth) and 54 species were restricted in their distribution to the central and southern part due to temperature barrier. The excluding of this number of species from the list has led to the possibility of finding only 25 species in the shallow water of northern part of the Red Sea, indicating that the collected number of species (32 species) represents a considerable amount of the expected fauna.

The examination of the data showed that the Gulf of Aqaba is richer in holothuroid fauna (20 species) than the Gulf of Suez (11 species) which could be attributed to the lower microhabitats and the very poor reefs in the Gulf of Suez. The same pattern was also evident for many groups of marine organisms by Head (1987). Also, the prevailing southerly winds may blow silts into the Gulf of Suez (Fishelson, 1971), in addition to the shallow depth and the heavy pollution in the Gulf of Suez. All these unfavorable conditions, have led to the lower similarity of the holothurian fauna in the Gulf of Suez than other parts of the Red Sea. Campbell (1987) assumed that central and northern Red Sea have the richest fauna, where the varying microhabitats in the Red Sea has enriched the holothuroid fauna. This is due to the fact that each habitat is preferred by one or more species of holothuroids (Shlesinger, 1983 and Behairy et al., 1984).

The present study revealed that seven specics were recorded for the first time from the entire Red Sea with its two Gulfs (Aqaba and Suez). These are Bohadschia mitsioensis, Bohadschia vitiensis (from Gulf of Aqaba and Red Sea), Holothuria (Thymiosycia) conusalba (from Red Sea and Gulf of Suez), Labidodemas rugosum, Holothuria (Platyperona) crosniert, Holothuria (Mertensiothuria) albofusca and Stichopus horrens (from the Red Sea). The appearance of such new records may be attributed to the lack of intensive surveys in the area or to the difficulties in identification of species.

Revising the over all distribution of the recorded species showed that, from the 32 species recorded in present study, five are cosmopolitan species (15.6\%). These are Holothuria (Mertensiothuria) leucospilota, H.(Halodeima) atra, H.(Thymiosycia) hilla, H. (Thymiosycia) impatiens and Stichopus variegatus. Six other species (18.7\%) were considered world widely distributed. These are Bohadschia tenuissima, Holothuria (Halodeima) edulis, $H$. (Thymiosycia) arenicola, H. (Metriatyla) scabra, H. (Lessonothuria) pardalis and Synapta maculata. Three species $(9.4 \%)$ namely 
Holothuria (Mertensiothuria) papillifera, $H$. (Cystipus) sucosa, and Opheodesoma kamaranensis were endemic to the Red Sea. The remaining eighteen species $(56.3 \%)$ were restricted in their distribution to certain places in the Indo-Pacific region with similar environmental conditions. Such pattern of distribution was also reported for other groups of echinoderms by Thandar (1989); Hellal (1990); Kerr et al. (1993) and Kerr (1994).

In the present study, the recorded species of genera Actinopyga and Bohadschia were collected from different habitats and zones and mostly found clinging on hard substrates. According to Deichmann (1958) classification, these species are considered surf zone species (Deichmann's first category). While most of the recorded species in genus Holothuria are fugitive species (Deichmann's second category). They live partially concealed under coral fragments, sand, rocks ...etc. However, individuals of Holothuria (Lessonothuria) pardalis were collected from coral branches and their spicules include tables and buttons. These results contradict with Deichmann's classification, hence these species lies under the first category (surf zone). Species of the subgenera C'ystipus, Theelothuria and Metriatyla are capable of burrowing or digging in sand and found buried more or less completely in soft substrate. These species lies under Deichmann's third division (fossorial species). Accordingly, this group of animals are highly adapted to occupy different types of habitats which widen the range of their distribution along the coast.

From the above mentioned results, it was clear that before the use of spicules for indicating the affinity between the groups of species, more field work is needed on their ecology. This is especially the case since many taxa now established are subsequent to Deichmann's work and their ecological classification has not yet been sufficiently correlated with the present study. Moreover, the modification of spicules due to age and growth might need to be investigated in future studies.

\section{REFERENCES}

Behairy, A. A.; Beltagi, S. and Durgaprasada Rao, N. V. N. (1984). Grain size selection and carbonate sediments processing by sea cucumber Holothuria atra in the shallow marine environment of Jeddah, Eastern Red Sea. J. Fac. Mar. Sci., $4: 67-77$. 
Bemert, G. and Ormond, R. (1981). "Red Sea Coral Reefs." Keegan Paul International Ltd. London, $192 \mathrm{pp}$.

Campbell, A. C. (1987). Echinoderms of the Red Sea. In: "Key Environments Red Sea." A. J. Edwards \& S. M. Head (eds.) Pergamon Press, Oxford, 215-232.

Cherbonnier, G. (1952). Les Holothuires de Quey et Gimard. Mem. Inst. R. Sci. Nat. Belg., 44(2): 1-50.

Cherbonnier, G. (1955). Resultata scientifiques des campagnes de la "Calpso". Les Holothuires de la Mer Rouge. Annls. Inst. Oceanog. Monaco, 30: 129-183.

Cherbonnier, G. (1962). Les Holothuires de la Mer Rouge de l'universte Herbraque de Jerusalem. Bull. Seafish. Res. Stn. Israel, 27: 5-10.

Cherbonnier, G. (1967). Deuxieme contribution a l'etude des Holothuires de la Mer Rouge collectes par des Israeline. Bull. Seafish. Res. Stn. Israel, 26: 55-68.

Cherbonnier, G. (1979 a). Sur une nouvelle espece d'Holothuires Aspidochirote de Mer Rouge Holothuria (Metriatyla) tortonesei Nov. sp. Bull. Mus. Nat. Hist. Paris, $l$ (4) : 291294.

Cherbonnier, G. (1979 b). Holothuires nouvelle ou peu connues de la Mer Rouge (Echinodermes). Bull. Mus. Nat. Hist. Paris, 1(4): $861-870$.

Cherbonnier, G. (1980). Description d'une espece d'Holothuires Apode Protankyra suroitae nov. sp. Et d'le Echinide irregulier, Echinocyamus elegans Mazzetti recoltes dans le sud de la Mer Rouge. Bull. Mus. Nat. Hist. Paris, 2(4): 2730. 
Cherbonnier, G. (1988). "Fauna de Madagascar." Echinodermes: Holothuires. Orostom (eds.) 272 pp, 125 figs.

Clark, A. M. and Rowe, F. W. E. (1971). Monograph of shallow water Indo-West Pacific Echinoderms. Trustees Br. Mus. Nat. Hist., London, 277 pp.

Clark, H. L. (1921). The echinoderm fauna of Torres Straits: its composition and its origin. Pap. Dept. Mar. Biol., Carnegi Inst., 10: viii $+223,38$ pls.

Deichmann, E. (1958). The holothuroids collected by the Velero III and IV during the years 1932 to 1954. Part II. Aspidochirotida. Alan Hancock Pacif. Exped., 11: 249-349, 9 pls.

Evans, D.; Murray, J. W.; Biggs, H. E. J.; Bate, R. and Bush, P. R.; (1973). The oceanography ecology, sedimentology and geomorphology of parts of the Trucial Coast Barrier Island complex. Persian Gulf. In: "The Persian Gulf." Purser, B. H. (ed.) Springer-Verlag Berlin, Heidelberg, New York., 233-277.

Fishelson, L. (1971). Ecology and distribution of the benthic fauna in the shallow water of the Red Sea. Mar. Biol. Berlin, 10: 113-133.

Guille, A.; Laboute, P. and Menou, J. L. (1986). Guide des etoiles de mer oursins et outers echinodermes du lagoon de Nouvelle Caledonie. ORSTOM, $283 \mathrm{pp}$.

Hammond, L. S. (1982). Patterns of feeding and activity of deposit feeding holothurian and echinoids from a shallow back reef lagoon, Discovery Bay Jamaica. Bull. Mar. Sci.,32 (2): $549-571$.

Head, S. M. (1987). “ Key Environments Red Sea." Edwards, A. J. and Head S. M. (eds.) Pergamon press, Oxford, 1-21. 
Hellal, A. M. (1990). Taxonomical studies and zoogeography of echinoderm species (Brittle stars) from the Northern Red Sea. Ph. D. Thesis, Al-Azhar Univ., $350 \mathrm{pp}$.

Hughes-Clark, M. W. and Keij, A. J. (1973). Organisms as producers of carbonate sediment and indicators of environment in the southern Persian Gulf. In: "The Persian Gulf." Purser, B. H. (ed.) Springer-Verlag Berlin, Heidelberg, New York pp: 33-56.

Hughes, R. N. (1977). The biota of reef flat and limestone cliffs near Jeddah, Saudi Arabia. J. Nat. Hist., 11:77-96.

James, D. B. and Pearse, J. S. (1969). Echinoderms from the Gulf of Suez and northern Red Sea. J. Mar. Biol. Ass. India, 11 $(1 \& 2): 78-125$.

Kerr, A. M. C. (1994). Shallow water holothuroids (Echinodermata) of Kasrae, eastern Carolina Island. Pac. Sci., 48 (2): 161174.

Kerr, A. M. C.; Stoffels, E. M. and Yoon, R. L. (1993). Abundance, distribution of holothuroids (Echinodernata) on a wind ward and leeward fringing coral reef, Guam, marina Island. Bull. Mar. Sci., 52: 780-791.

Kimor, B. (1973). Plankton relation of the Red Sea, Persian Gulf and Arabian Sea. In: "The Biology of the Indian Ocean." Zeitzschel, B. (ed.) Springer-Verlag Berlin Heidelberg, New York, pp: 221-232.

Magnus, D. B. E. (1967). Ecological and ethological studies and experiments on the echinoderms of the Red Sea. Stud. Trop. Oceanog., 5: 635-664.

Moriarty, D. J. W. (1982). Feeding of Holothuria atra and Stichopus chloronatus on bacterial organic carbon and organic nitrogen in sediment of the Great Barrier Reef. Aust J. Mar. Freshw. Res., 33: 255-263. 
Panning, A. (1929-1935). Die gattung Holothuria. Mitt. Zool. St Inst. Hamb. 44 (1929): 91-1;38, 21 figs.; 45 (1934): 24-50, figs. 22-44; (1934): 65-84, figs. 45-71; (1935): 85-107, figs. 72$102 ; 46$ (1935): 1-18, figs. 103-121.

Pearson, J. (1914). Proposed reclassification of the genera Mulleria and Holothuria. Spolia Zeylan, 9(35): 163-172, 26 pls.

Price, A. R. G. (1981). Studies on the echinoderm fauna of the Western Arabian Gulf. J. Nat. Hist., 15: 1-15.

Price, A. R. G. (1982). Echinoderms of Saudi Arabia. Comparison between echinoderm faunas of Arabian Gulf, SE Arabia, Red Sea and Gulfs of Aqaba and Suez. Fauna of Saudia Arabia, 4: 3-21.

Price, A. R. G. (1983). Echinoderms of Saudi Arabia. Echinoderms of the Arabian Gulf Coast of Saudi Arabia. Fauna of Saudia Arabia, 5: 28-108.

Rowe, F. W. E. (1969). A review of the family Holothuriidae. Bull. Br. Mus. Nat. Hist. (Zool.), 18(4): 119-170.

Shlesinger, A. (1983). Ecological studies on the holothurian Actinopyga banwwarthi after a phosphate accident in Eilat Port, Gulf of Aqaba. Mar. Biol., 12: 45-52.

Sloan, N. A.; Clark, A. M, and TayJor, J.D. (1979). The echinoderms of Aldabra and their habitats. Bull. Br. Mus. Nat. Hist. (Zool.), 37(2): 81-128, 22 figs.

Thandar, A. S. (1989). Zoogeography of South African echinoderm fauna. S. Afr. J. Zool., Tydskr, Dierkd, 24(4): 311-318.

UNESCO. (1976). Marine science program of the Red Sea. Unesco Tech. Mar. Sci., 25: 1-25.

Yamaguchi, T. (1956). The daily activity rhythms of the holothurians in the coral reef of the Palao Island. Bull. Seto. Mar. Biol. Lab., 5: 603-635, 1 pl. 
STUDY ON THE HOLOTHUROID FAUNA

( ECHINODERMATA : HOLOTHUROMEA) INHABITING THE SHALLOW WATERS OF THE EGYPTLAN RED SEA

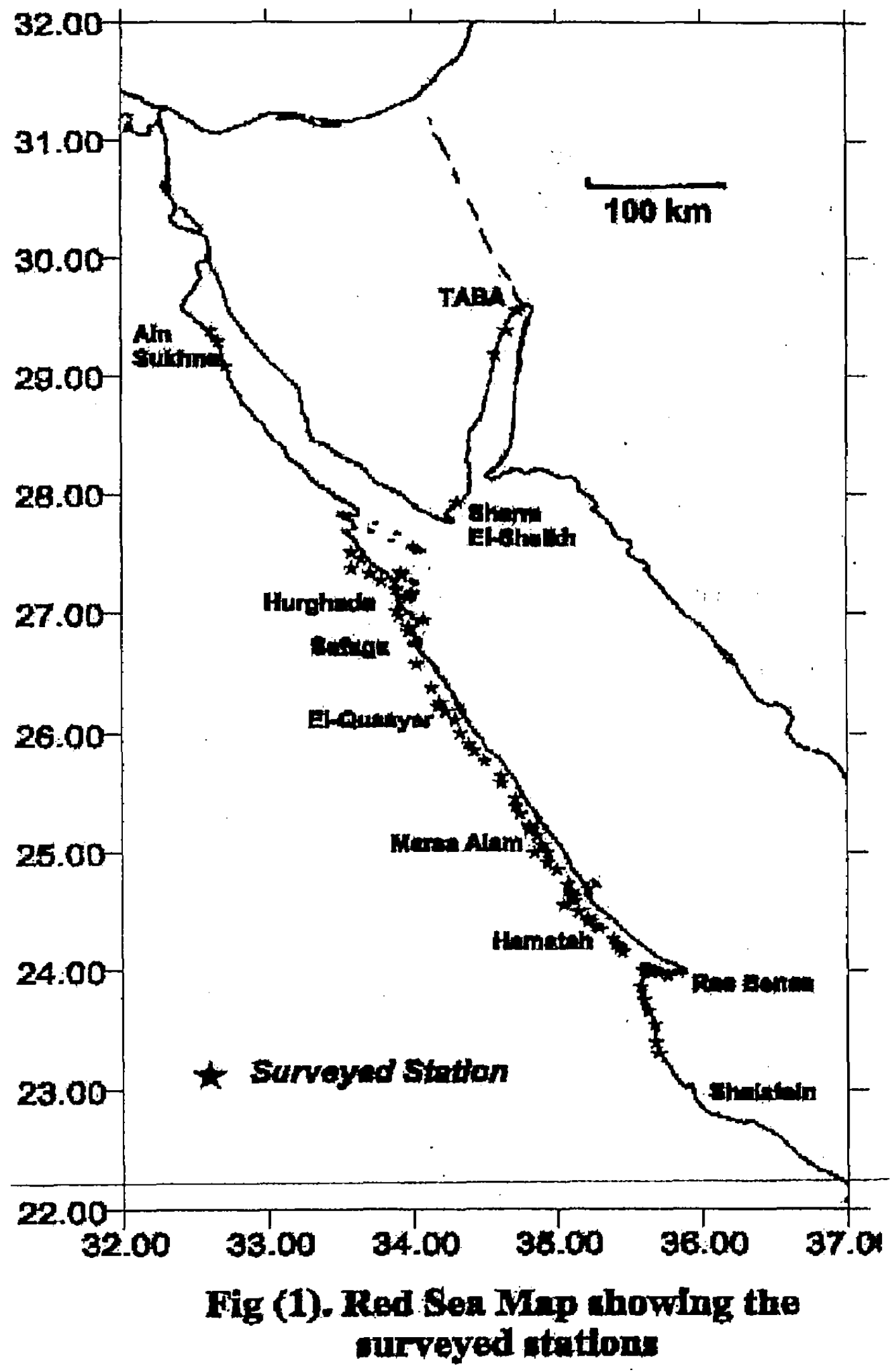




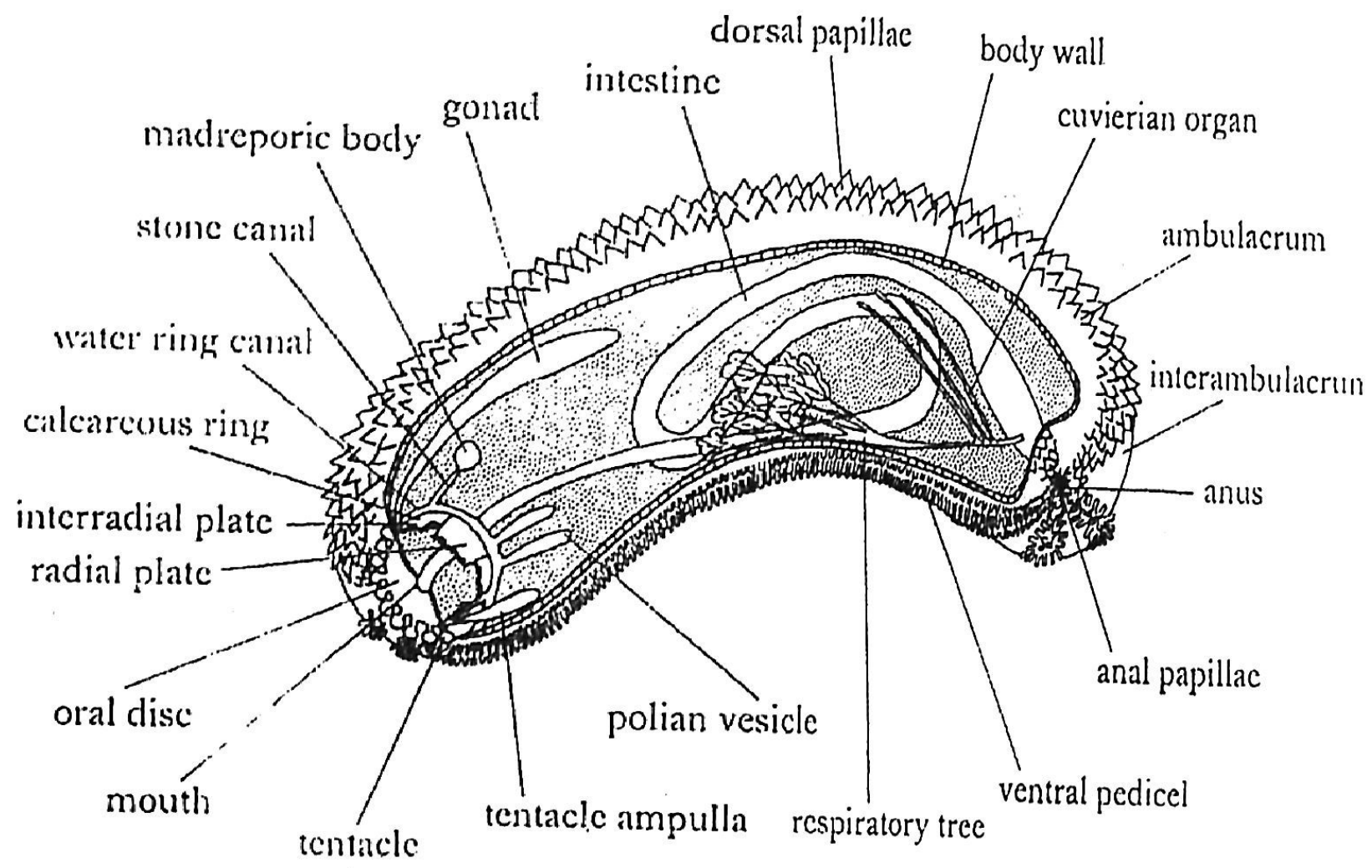

Figure (2) Introductory figure for holothurians (after Clark \& Rowe, 1971) 
PLATE 1: Examples of spicules from the examined species

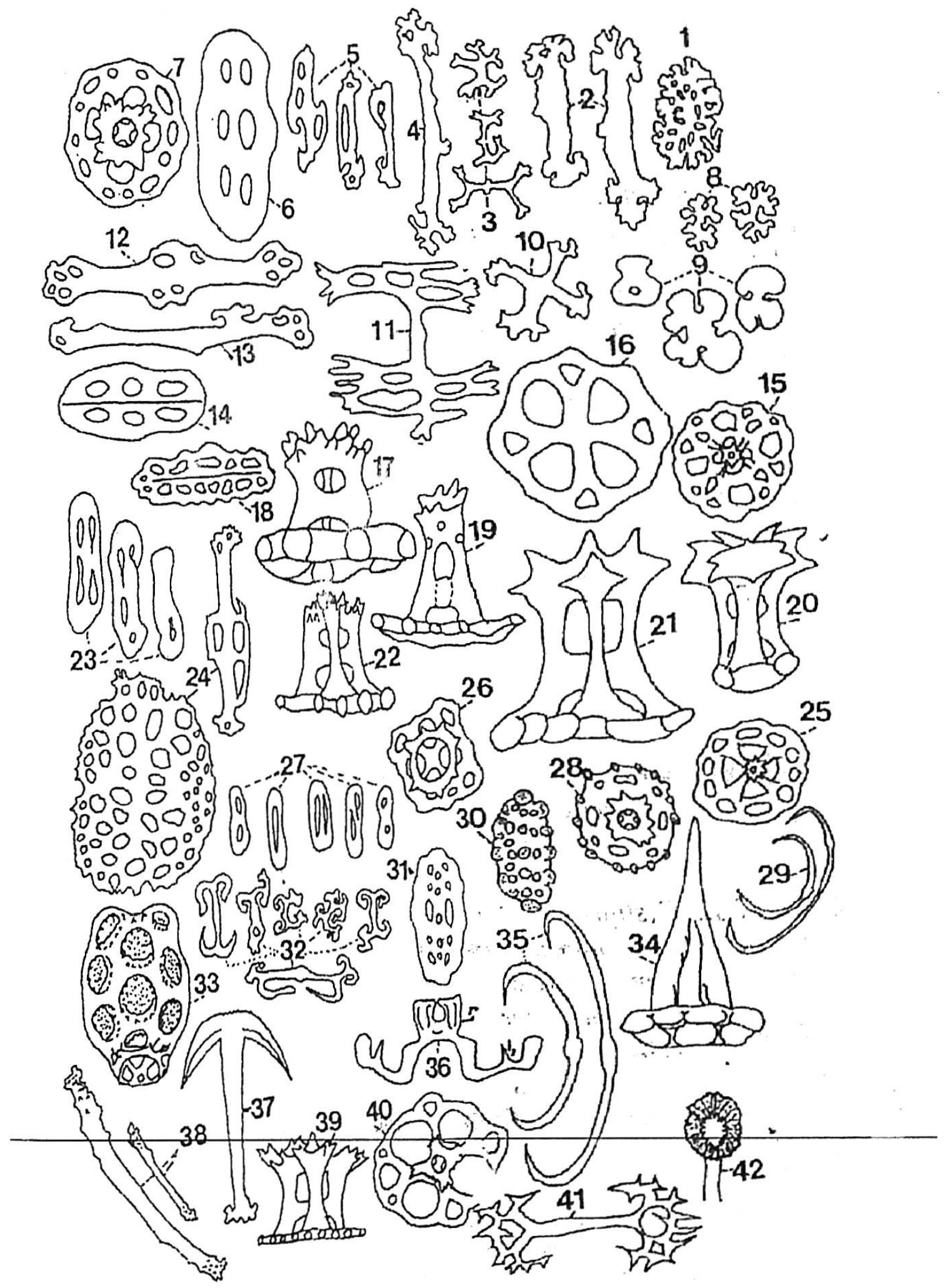




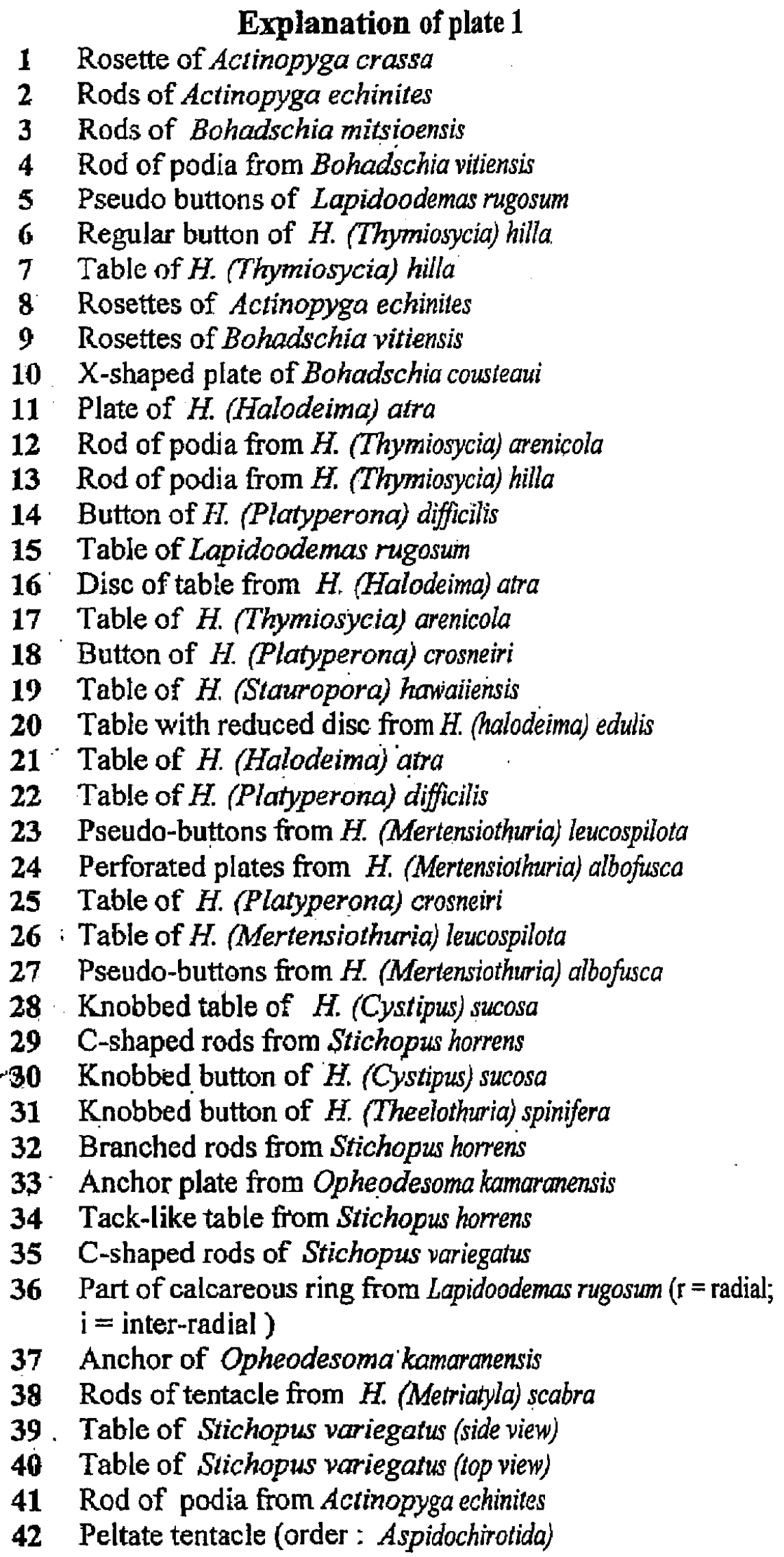

